\title{
Current status of knowledge of Sri Lankan mycota
}

\author{
Karunarathna $\mathrm{SC}^{1,2,3,4}$, Udayanga $\mathrm{D}^{1,2,3}$, Maharachchikumbura $\mathrm{SN}^{1,2,3}$, Pilkington $\mathrm{M}^{3}$, \\ Manamgoda DS ${ }^{1,2,3}$, Wijayawardene $\mathrm{DNN}^{1,2,3}$, Ariyawansa $\mathrm{HA}^{1,2,3}$, Bandara $\mathrm{AR}^{1,2,3}$, \\ Chukeatirote $\mathrm{E}^{1,2}$, McKenzie EHC ${ }^{6}$ and Hyde $\mathrm{KD}^{1 *, 2,3,4,5}$ \\ ${ }^{1}$ Institute of Excellence in Fungal Research, Mae Fah Luang University, Chiang Rai 57100, Thailand \\ ${ }^{2}$ School of Science, Mae Fah Luang University, Chiang Rai 57100, Thailand \\ ${ }^{3}$ Mushroom Research Foundation, 128 M.3 Ban Pa Deng T. Pa Pae, A. Mae Taeng, Chiang Mai 50150, Thailand \\ ${ }^{4}$ International Fungal Research \& Development Centre, The Research Institute of Resource Insects, Chinese Academy \\ of Forestry, Kunming 650034, China \\ ${ }^{5}$ Botany and Microbiology Department, College of Science, King Saud University, Riyadh, Saudi Arabia \\ ${ }^{6}$ Landcare Research, Private Bag 92170, Auckland, New Zealand
}

Karunarathna SC, Udayanga D, Maharachchikumbura SN, Pilkington M, Manamgoda DS, Wijayawardene DNN, Ariyawansa HA, Bandara AR, Chukeatirote E, McKenzie EHC, Hyde KD 2012 - Current status of knowledge of Sri Lankan mycota. Current Research in Environmental \& Applied Mycology 2(1), 18-29, Doi 10.5943/cream/2/1/2

The Sri Lankan mycota is inadequately described, although there are a number of studies on its biodiversity. Current estimates suggest that there could be as many as 25,000 species, of which only a little more than 2,000 are presently known, and this estimate does not take into account the large number of exotics introduced with food, plantation, and ornamental plants. In addition, only limited parts of the island have been explored. The available information is widely dispersed, difficult to access, and plagued by synonymy. This paper describes the current status of Sri Lankan Mycology, and makes suggestions for facilitating further research.

Key words - biodiversity - lichens - microfungi - mushrooms - phytopathogens - quarantine

\section{Article Information}

Received 20 March 2012

Accepted 28 March 2012

Published online 27 April 2012

*Corresponding author: Kevin David Hyde - e-mail - kdhyde3@gmail.com

\section{Introduction}

Sri Lanka, though small, has a great deal of biodiversity. This is due in part to the close juxtaposition of areas widely diverse in altitude and rainfall. Sri Lanka has 2,500 years of recorded history and a prehistory of several thousand years of human habitation. During this time it has developed a cultural sensitivity to the environment and, although little of its primary forest remains, the patterns of local agriculture have left areas of floristic diversity relatively intact. Tropical and subtropical regions are potentially the richest source of new fungal species, and Sri Lanka is no exception.
Information available on Sri Lankan fungi is scattered. There are difficulties in estimating exact numbers due to synonyms used and duplicate entries. The library at the Peradeniya Botanical gardens contains the works of T. Petch and D. N. Pegler together with an extensive collection of original illustrations of agarics, but few publications of a later date. Their original collections of macrofungi, and some of microfungi however, are now located at Kew. This absence of original collections including types makes the clarification of synonymies amongst the fungi very difficult, since herbarium specimens have to be obtained from Kew, an expensive and 
time consuming procedure. Because of their obvious economic importance the collections of soil fungi and plant pathogens are abundant, as is the relevant literature.

This paper will address the current status of Sri Lankan Mycology, and makes suggestions for facilitating further research.

\section{Geography}

Sri Lanka lies between latitudes $5^{\circ} 55^{\prime}$ and $9^{\circ} 51^{\prime}$ north and longitudes $79^{\circ} 41^{\prime}$ and $81^{\circ}$

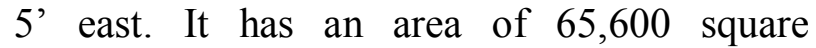
kilometers and comprises three physiogeographic units: the highlands, the midlands, and the lowlands. The highlands have an elevation of over 1,600 meters, and the midlands of between 1,600 and 300 meters; together they comprise the south central montane zone encircled by the vast lowland plains. There are also three regions demarcated by rainfall: the arid zone with an annual rainfall of $60-125 \mathrm{~cm}$, the dry zone with $125-190 \mathrm{~cm}$, and the wet zone with over $190 \mathrm{~cm}$. The wet zone comprises the montane zone, and the western and south western lowlands. Small parts of the North West and south east belong to the arid zone whilst the rest of the lowlands make up the dry zone (Fernando 1968).

\section{History of Sri Lankan Mycology}

The first Sri Lankan fungi to be recorded were Peziza ceylonische and $P$. lembosa described by Houttyn in 1783. Later work by Berkeley \& Broome (1870, 1871, 1873), Petch (1908a, 1908b, 1910, 1913, 1915a, 1915b, 1916a, 1916b, 1916c, 1917a, 1917b, 1919, 1922, 1923, 1924a, 1924b, 1924c, 1924d, 1925, 1926a, 1926b, 1927, 1928, 1945, 1948), and Petch and Bisby (1950) have raised the number of described species to over 2,000 in about 640 genera. T. Petch, a British mycologist worked at the Royal Botanical Gardens in Peradeniya between 1900 and 1925, also documented various plant pathogens and other fungi (Ainsworth 1976, Petch 1925).

Certain groups of fungi have been studied more intensively than others, because of their prominence (macrofungi), or practical importance (phytopathogens and mycorrhizae). The number of records in Uredinales are, Uredo (58 species), Puccinia (41 species),
Coleosporium (3 species), Uromyces (19 species), Hemileia (1 species), Melampsora 4 species, Pucciniastrum 2 species, Aecidium 20 species, Blastopota 1 species, Cerotelium (1 species), Cystospora (1 species), Diorchidium (3 species), Phragmidium (4 species), Ravenelia (8 species), Scopella (1 species); making a total of 168 species Berkeley \& Broome (1870-1877), Petch (1908-1948), and Petch \& Bisby (1950). In Ustilaginales 25 species belong to 7 genera, in Exobasidiales 2 species belong to single genus.

The larger Basidiomycetes are presently the best known group in Sri Lanka, with records of 513 species of agarics in 50 genera such as Psalliota (Agaricus) 35 spp., Pleurotus 12 spp., Marasmius 53 spp., Lentinus 14 spp. and Hygrophorus 27spp. Petch \& Bisby (1950); Coomaraswamy (1979, 1981a); Coomaraswamy \& De Fonseka (1981b); Coomaraswamy \& Kumarasingham (1988). The Herbarium of Horticultural Crop Research and Development Institute (HORDI), Gannoruwa, Peradeniya, Sri Lanka has 412 paintings of agarics by W. de Alwis, which are now available in digital form. A comprehensive Agaric Flora of Sri Lanka was published by Pegler (1986). In the 'Aphyllophorales', 342 species in 51 genera have been recorded. The dominant genera are, Polyporus (57 species), Fomes/Rigidoporus (32 species), Poria (23 species) and Stereum (26 species). Seventy five species of Gasteromycetes in 37 genera have been recorded, the dominant genera being: Geastrum (9 species) and Cyathus (4 species). In total, 1125 species in 162 genera Berkeley \& Broome (1870-1877), Petch (1908-1948), and Petch \& Bisby (1950). Seventy-two species of Zygomycota in 17 genera, mostly soil inhabitants, have been recorded, as have 252 Ascomycetes, mostly entomo- or phytopathogens. Only 130 species of Myxomycota in 30 genera have been recorded in Sri Lanka (Petch \& Bisby 1950) and there are no records thereafter, probably due to their lack of economic importance and the absence of local expertise.

Most references to the fungi in Sri Lanka are found scattered in journals, research reports, research institutions, University proceedings and theses. 


\section{Macrofungi}

There have been very few studies on the taxonomy and phylogeny of the macrofungi in Sri Lanka since Houttuyn 1783; Berkeley \& Broome from 1870-1877; Petch from 19051925; Petch \& Bisby (1950); Coomaraswamy (1979, 1981a); Pegler (1986); Coomaraswamy \& Kumarasingham (1988). Over 500 species of agarics have been described or recorded, mostly by M.J. Berkeley, from the collections of G. Gardner, who was the Superintendent of the Royal Botanic Gardens, Peradeniya during 1844-1849. G. H. K. Thwaites, who took an interest in the fungi helped Gardner at Peradeniya and sent over 1200 dried specimens to M. J. Berkeley at Kew, for identification. Berkeley \& Broome described 403 agaric species, of which 305 provided the type collections for new species (Berkeley \& Broome 1870, 1871, 1873). Based on O. Beccari's collections in 1865, Cesati (1879) described a few agaric species a few years after Berkeley and Broome's publications. F. V. Höhnel visited Sri Lanka in 1907 and rediscovered some of Berkeley \& Broome specimens (Höhnel 1908, 1909, 1914). T. Petch who was appointed Mycologist at Peradeniya Royal Botanic Gardens collected mushrooms extensively on the island and published many accounts during 1905-1925. The genera Lepiota (Pegler 1972) and Inocybe (Horak 1979, 1980), and the family Entolomataceae (Pegler 1977, Horak 1980) were taken in to account concerning the recent publications of agarics. More recently Lentinus giganteus Berk. has been transferred to Pleurotus based on Thai and Sri Lankan collections (Karunarathna et al. 2011), and a new species of Agaricus was described from Kandy district (Karunarathna et al. 2012).

\section{Phytopathogenic fungi in Sri Lanka}

Sri Lanka has a wide diversity of crops in different agro-ecological settings (Jayawardena and Weerasena 2000). These include plantation crops: tea, rubber, and coconut; field crops: rice, legumes and maize; export crops: cloves, nutmeg, pepper, cocoa, and cardamom; timber crops: teak, jak, and mahogany; fruit trees: banana, passion fruit, and papaya; plus a diverse range of forest trees, and medicinal, fodder, and ornamental plants.
Sri Lanka has a century long tradition of research into phytopathogens (Ainsworth 1976). Numerous handbooks (UNESCO: Man and the Biosphere (MAB) National Committee for Sri Lanka publications) on the fungi parasitic on plants, associated with insects, or found in soil were published in the 1970s and 1980s (Coomaraswamy 1979, 1981a; Coomaraswamy \& De Fonseka 1981b; Coomaraswamy \& Kumarasingham 1988). Several countrywide checklists have been published (Coomaraswamy 1979). A list of plant pathogenic fungi with host names prepared by S. Sivanathan (unpublished) is being updated.

\section{Impact of plant pathogens, quarantine and law enforcement}

There are detailed records of the serious damage caused by coffee rust (Hemileia vastatrix) in 1870 , which defoliated the plants, and virtually ended coffee production in the Island causing the British to change their drinking habits: tea became more popular (Daniel 1993, Waller et al. 2007, Vandermeer et al. 2009). Concern about plant quarantine began in 1869, after the coffee rust disease wiped out nearly all the coffee plantations in Sri Lanka, and Indonesia banned import of both coffee and coffee sacks from Sri Lanka. This was Asia's first plant quarantine regulation (http://www.agridept.gov.lk/). In Sri Lanka, British scientists in the Department of Agriculture at Peradeniya began to quarantine plants in 1880's, and Sri Lanka became a centre for the identification of pests and diseases affecting crops, as countries in the region began sending material for identification. After the establishment of the Central Agricultural Research Institute (CARI) at Gannoruwa, Peradeniya, all plant quarantine activities were carried out there by the departments of Entomology and Plant pathology. In the early 1980's the Australian government helped establish a separate unit for Plant quarantine within the premises of CARI, and a chief Plant Quarantine officer was appointed with all responsibility for the whole island. In 1994, the present National Plant Quarantine Service complex was established at Katunayake with the help of the Japanese Government. The Plant Protection Act No.35 

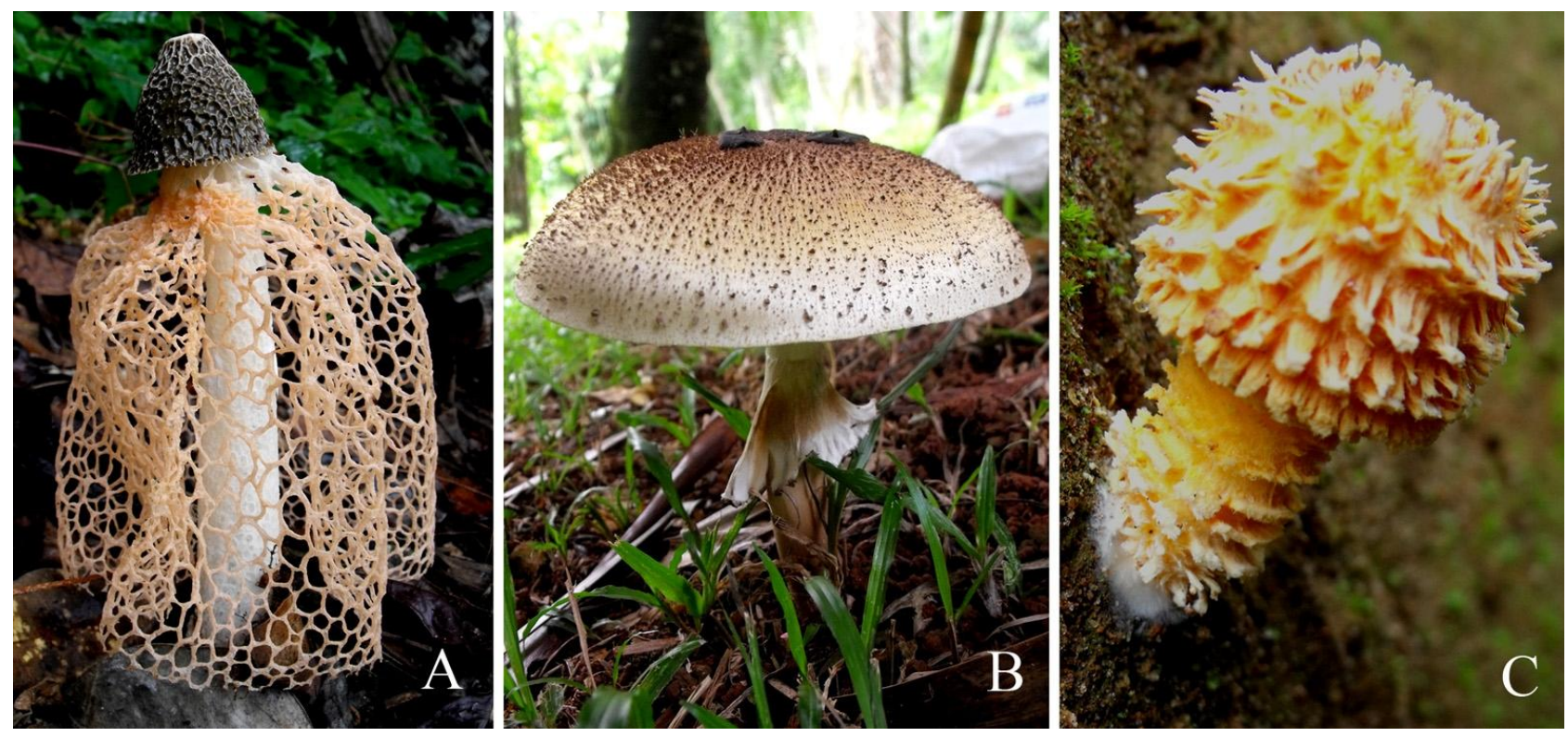

Fig. 1 - Some macrofungi observed during recent field visits in Sri Lanka A Phallus indusiatus Vent. B Clarkeinda trachodes (Berk.) Singer. C Agaricus trisulphuratus Berk. Photo credit : Samantha C. Karunarathna.

of 1999 is an approved act to make provisions against the introduction in to Sri Lanak and the spreading therein, of any organism harmful to, or injurious or destructive of plants and for the sanitation of plants in Sri Lanka (http://www.customs.gov.lk/docs).

Divisions in major research stations have been established to carry out research on the pathogens affecting the crops. They work on issues such as diversity, ecology and the management of diseases. With the rapid advance of research in fungal pathogens, the older checklists and countrywide databases such as the Diseases of cultivated plants in Ceylon by Abeygunawardhane (1969), Fungi oparasitic on the plants of Sri Lanka (Coomaraswamy 1979) quickly become outdated (Cai et al. 2011b; Ko Ko et al. 2011). Accurate identification and naming of pant pathogens provide information essential for determining the appropriate disease control measures (Rossman \& Palm-Hernández 2008). It is, therefore, imperative to recollect plant pathogens, re-identify, re classify and document the up-to-date information. Table 1 summarizes the most commonly documented phytopathogenic fungi on major crops (tea, rubber, coconut, rice), based on available literature. However the lists need updating and the identifications should be confirmed in future studies.

\section{Post harvest fungal diseases in Sri Lanka}

In developing countries more than $30 \%$ of agricultural produce is lost between harvesting and consumption (Coursey \& Proctor 1973, Kader 2005). Of the pathogens responsible for post-harvest loss fungi are the most important (Monica et al. 2010). Among the significant post-harvest fungal diseases of Sri Lankan fruit are: anthracnose on banana, papaya and mango (Colletotrichum spp.), stem end rot in banana, avocado, papaya, mango, and rambutan (Botryodiplodia theobromae); water blister in pineapple (Theilaviopsis paradoxa); green mould (Penicilium digitatum) and blue mould (Penicillium italicum) in Citrus fruits; and Phytopthora and Phomopsis rot in various fruits (Sivanathan \& Adikaram 1989a, b; Adikaram et al. 1992; Adikaram \& Karunarathne 1998; Sivakumar et al. 1997; Abayasekara et al. 1998; Karunanayake et al. 2007; Wijeratnam \& Sarananda 2008). The past two decades have seen various studies on the resistance of Sri Lankan produce to postharvest diseases, defense mechanisms and methods of control have also been studied (De Silva et al. 2005, Herath \& Abeywickrama 2008). Recent surveys and reviews of tropical post-harvest pathogens have revealed an urgent need for the re-inventory of tropical pathogens, because modern molecular techniques have shown the confusion of previous studies. 
Current Research in Environmental \& Applied Mycology Doi 10.5943/cream/2/1/2

Table 1 Common plant pathogen recorded in Sri Lanka on major crops (tea, rubber, coconut and rice)

\begin{tabular}{lll}
\hline Host and fungus & Disease & References \\
\hline Coconut & & \\
\hline Bipolaris incurvata & Leaf blight disease & http://www.srilankanwebdesign.com/coconut1/ \\
Ceratocystis paradoxa & Stem bleeding & Alfieri 1967 \\
Ganoderma sp. & Ganoderma disease & http://www.srilankanwebdesign.com/coconut1/ \\
Pestalotiopsis palmarum & Grey blight & Holliday 1995 \\
Phytophthora palmivora & Bud Rot & http://www.srilankanwebdesign.com/coconut1/
\end{tabular}

\begin{tabular}{l} 
Rice \\
\hline Alternaria padwickii \\
Cercospora janseana \\
Cercospora janseana \\
Cochliobolus miyabeanus \\
Gerlachia oryzae, \\
(Rhynchosporium oryzae) \\
Gibberella fujikuroi (Fusarium \\
moniliforme) \\
Magnaporthe grisea \\
(Pyricularia oryzae) \\
Magnaporthe salvinii \\
Many fungal species and \\
bacteria \\
Rhizoctonia solani \\
Sarocladium oryzae \\
Ustilaginoidea virens
\end{tabular}

$\begin{array}{ll}\text { Stackburn } & \text { Seneviratne \& Jeyanandarajah 2004 } \\ \text { Narrow brown leaf spot } & \text { Dissanayake \&_Wickramasinghe 1999 } \\ \text { Narrow brown leaf spot } & \begin{array}{l}\text { Seneviratne \& Jeyanandarajah 2004 } \\ \text { Brown spot }\end{array} \\ \text { Leaf scald } & \text { Seneviratne \& Jeyanandarajah 2004 } \\ \text { Bakanae disease } & \text { Seneviratne \& Jeyanandarajah 2004 }\end{array}$

Rice blast

Stem rot

Grain spotting and pecky http://www.agridept.gov.lk/index.php/en/crop-

rice

Sheath blight

Sheath rot

False smut

Nugaliyadde et al. 2000, Seneviratne \& Jeyanandarajah 2004

Seneviratne \& Jeyanandarajah 2004

recommendations/809

Nugaliyadde et al. 2000

Nugaliyadde et al. 2000

http://www.knowledgebank.irri.org/IPM/index.php/fals e-smut

\section{Rubber \\ Colletotrichum acutatum}

Colletotrichum gloeosporioides

Corynespora cassiicola

Fusarium solani

Geotrichum sp.

Nattrassia mangiferae

(Neofusicoccum mangiferae)

Phytopthora spp.

Rigidoporus microporus

Sclerotium rolfsii

Thanatephorus cucumeris

\section{Colletotrichum leaf disease}

Jayasinghe \& Fernando 1997

\section{Colletotrichum leaf} disease

Corynespora leaf fall

Fusarium wilt

Geotrichum association on roots

Foot canker, sudden wilt

Leaf fall, bark rot, shoot die-back and pod rot

White root disease

Collar rot

Target leaf spot
Jayasinghe \& Fernando 1997

Liyanage et al. 1986, Jayasuriya \& Thennakoon 2007a

Liyanage \& Dantanarayana 1983

Jayasinghe \& Wettasinghe 1996

Jayasinghe \& Silva 1994

Jayasuriya et al. 2007

Jayasuriya \& Thennakoon $2007 \mathrm{~b}$

Jayasinghe et al. 1988

Jayasinghe 1993

\begin{tabular}{l} 
Tea \\
\hline Exobasidium vexans \\
Kretzschmaria deusta (Ust \\
deusta) \\
Macrophoma theicola \\
Nemania diffusa (Syn. \\
Hypoxylon vestitum) \\
Phomopsis theae \\
Poria hypolateritia \\
Rosellinia arcuata
\end{tabular}

\section{Blister blight}

Charcoal rot

Macrophoma canker

Wood decay

Colar and branch canker

Poria root disease

Black root disease
Holliday 1995

Muraleedharan 2007

Thseng et al. 2004

Balasuriya \& Adikaram 2008

Holliday 1995

Wijesundera \& Kulatunga 1993

Muraleedharan 2007 

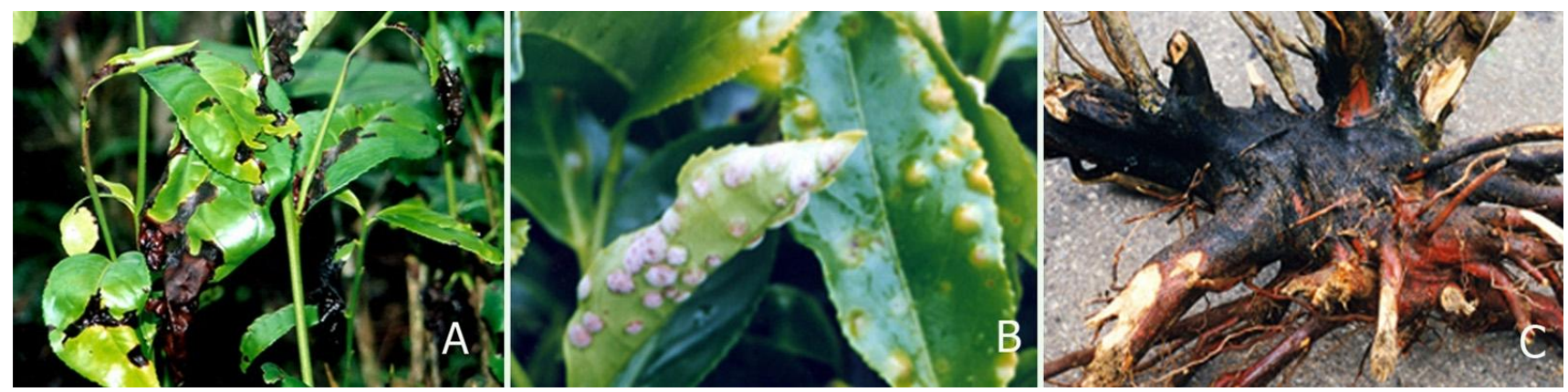

Fig. 2 - Some common fungal diseases on tea in Sri Lanka A Black blight caused by Rhizoctonia solani. B Blister blight caused by Exobasidium vexans. C Violet root disease caused by Sphaerostilbe repens. Photo credit : Tea Research Institute, Talawakelle, Sri Lanka.

(Phoulivong et al. 2010 a, b, Cai et al. 2011a, Ko Ko et al. 2011). For instance, Phoulivong et al. (2010a) compared the various Colletotrichum isolates from tropical fruits, and found that morphologically similar isolates from chilli, mango, papaya, rose apple and jujube may comprise more than one distinct species, which are currently poorly defined and characterized. Alahakoon et al. (1994) reported Colletotrichum gloeosporioides on 23 fruit crops in Sri Lanka including durian, mangosteen, pini jambu (wax apple), rambutan and 11 other less economically important fruit trees, hosts on which this pathogen had not been previously recorded. These studies have shown that fruit diseases have a considerable impact in Sri Lanka, and that a modern revisionary treatment needs to be carried out. Analysis and comparison of sequence and morphological data, followed by epitypifi-cation, will fundamentally change our understanding of these species, not only in Colletotrichum, but also in many other important tropical plant pathogenic genera such as Botryosphaeria, Fusarium, Pestalotiopsis, Phomopsis and Phyllosticta (Udayanga et al. 2011; Wikee et al. 2011; Cai et al. 2011a, b; Maharachchikumbura et al. 2011; Manamgoda et al. 2011; Liu et al. 2011). Given the economic importance of these diseases further studies are urgently needed.

\section{Lichenological studies}

G.H.K. Thwaites first collected Sri Lankan lichens in 1868. W.A. Leighton examined Thwaites' collections and identified 199 species (Leighton 1870). Almquist's collection of 1879 formed the basis of Nylander's Lichenes Ceylonenses of 1900.
Eighty nine lichen species common around Kandy were recorded by A.H.G. Alston (Alston 1932). Between 1966 and 1968 S. Kurokawa and M. Mineta reported lichens mainly from the montane forests (Kurokawa and Mineta 1973), and F. Hale collected lichens in lowland rain forests during 1970's. The regional monographs of Relicina and Thelotremataceae in Sri Lanka were based upon the above collections (Hale 1980, 1981). W. Brunnbauer compiled a bibliographic description of lichens in Sri Lanka in 15 fascicles which included 550 species belonging to 122 genera and 48 families, following a botanical excursion from the University of Vienna in 1984 (Brunnbauer 1984-1987). A. H. M. Jayasooriya recorded 17 species of lichens from Ritigala (Jayasuriya 1984). C. Wijerathne described 35 new lichen species from Ritigala Mountains and its vicinity during 1999-2003. The publications of Moberg (1986, 1987), Awasthi (1991), Makhija \& Patwardhan (1992), Breuss et al. (1997) and Vezda et al. (1997) increased the number of recorded lichens to 659 species. In 2009 a preliminary survey of lichens was conducted as a workshop at University of Peradeniya, and the participants collected 98 different species (Jayalal et al. 2008). N.M.C. Nayanakantha and S. Gajameragedara described about 50 lichens from Kandy municipal region in 2003 (Nayanakantha \& Gajameragedara 2003, Jayalal et al. 2008). Two new additional lepraioid lichens were described by Orange (2001). A survey carried out by M.K. Karunarathna in 2006 listed 23 genera of lichens (Jayalal et al. 2008). A survey at Horton Plains National Park during 2004-2006, found 1515 specimens of macrolichens, 
identified 293 species in 48 genera, four new to Sri Lanka, belonging to 13 families (Jayalal et al. 2008). In all 696 species of Sri Lankan lichens are currently reported (Jayalal et al. 2008), but ongoing research and unpublished data could raise this number to over 1500 species.

\section{Conclusion}

The identification of mushrooms, plant pathogens, and other fungi is an important part of Sri Lankan mycological research. There is an urgent need for both a national collection of fungi and a network of local working groups. It is important to have a focal point for mycological activities within the national herbarium, which would coordinate the identification and documenting of all fungi locally. The maintenance of national collection for living cultures and collaborative efforts to apply molecular based identification and updating the knowledge is also emphasized. Finally we would like to appreciate international and local mycologists for their great work on the developments Sri Lankan mycology.

\section{Acknowledgements}

We are grateful to Else Vellinga (Department of Plant and Microbial Biology, University of California, Berkeley, USA), for her valuable discussion. Our special thank goes to Dharmapriya Samansiri (Tea Research Institute, Sri Lanka), for providing tea disease images. This study was financially supported by the project Value added products from basidiomycetes: Putting Thailand's biodiversity to use (BRN049/2553), the National Research Council of Thailand (NRCT), the project - Taxonomy, Phylogeny and cultivation of Lentinus species in northern Thailand (NRCT/55201020007), Mae Fah Luang University, the project - Taxonomy, Phylogeny and cultivation of Lentinus species in northern Thailand (MFU/54 1010200 48).

\section{References}

Abayasekara C, Ratnayake S, Adikaram NKB. 1998 - Resistance of banana fruit to fungal disease: an overview, In: Johnson GI, Highley E, Joyce DC (eds), Disease resistance in fruit, ACIAR Proceedings No. 80, Canberra 39-45.

Abeygunawardhane DVW. 1969 - Diseases of cultivated plants in Ceylon. The Colombo. Apothecaries Ltd 238-240.

Adikaram NKB, Karunaratne A. 1998 Suppression of anthracnose and stem end rot in avocado by endogenous antifungal substances and a natural inhabitant Pestalotiopsis sp. ACIAR Proceedings No. 80. Disease Resistance in Fruits 72-77.

Adikaram NKB, Ewing D, Karunaratne AM, Wijeratne EMK. 1992 - Antifungal compounds from immature avocado. Phytochemistry 31, 93-96.

Ainsworth GC. 1976 - Tom Petch, B.A., B.Sc. Transactions of the British Mycological Society 67, 179-181.

Alahakoon PW, Brown AE, Sreenivasaprasad 1994 - Genetic characterization of Colletotrichum gloeosporioides isolates obtained from mango. International Journal of Pest Management 40, 225229.

Alfieri SA. 1967 - Plant Pathology Circular No.53. Florida Department of Agriculture Division of Plant Industry.

Alston AHG. 1932 - The Kandy Flora. The Government Press, Colombo 78-80.

Awasthi DD. 1991 - A key to the microlichens of India, Nepal and Sri Lanka. Bibliotheca Lichenologica 40, 207-302.

Balasuriya A, Adikaram NKB. 2008 Polyhydroxylated steroids from an endophytic fungus, Chaetomium globosum. Applied Microbiology and Biotechnology 80, 241-252.

Berkeley MJ, Broome CE. 1870 - On some species of the genus Agaricus from Ceylon. Transactions of the Linnean Society 27, 149-152.

Berkeley MJ, Broome CE. 1871 - The Fungi of Ceylon (Hymenomycetes, from Agaricus to Cantharellus). Botanical Journal of Linnean Society 14, 29-140.

Berkeley MJ, Broome CE. 1873 - Enumeration of the fungi of Ceylon. Part 2. Botanical Journal of Linnean Society 11, 494-567. Breuss O, Brunnbauer W. 1997 - Flechten aus Sri Lanka. Annalen des Naturhistorisches Museum Wien Botanische 
99B 727-735.

Brunnbauer W. 1984-1987 - Die Flechten on Sri Lanka in der literature. Naturhistorisches Museum Wien Botanische Abteilung (in 14 teilen, als kopian verteilt) $433 \mathrm{~S}$.

Cai L, Giraud T, Zhang N, Begerow D, Cai G, Shivas RG. 2011a - The evolution of species concepts and species recognition criteria in plant pathogenic fungi. Fungal Diversity DOI 10.1007/s13225011-0127-8.

Cai L, Udayanga D, Manamgoda DS, Maharachchikumbura SSN, McKenzie EHC, Guo L, Liu X, Bahkali AH, Hyde KD. $2011 b$ - The need to carry out reinventory of plant pathogens. Tropical Plant Pathology 36, 205-213.

Cesati V. 1879 - Mycetum in itinere Borneensi lectorum a cl. Od. Beccari. Atti Accad. Sci. Fis. Matem. Napoli 8, 1-28.

Coomaraswamy U. 1979 - A handbook to the fungi parasitic on the plants of Sri Lanka MAB-UNESCO Publication No. 4 (Sri Lanka: National Science Council).

Coomaraswamy U. 1981a - A handbook to the agarics of Sri Lanka MAB-UNESCO Publication No. 5 (Sri Lanka: National Science Council).

Coomaraswamy U, De Fonseka RN. 1981b - A handbook to the soil fungi of Sri Lanka, MAB-UNESCO Publication No. 7 (Sri Lanka: National Science Council).

Coomaraswamy U, Kumarasingham S. 1988 A handbook to the macrofungi of Sri Lanka. Natural Resources, Energy and Science Authority, Sri Lanka 124.

Coursey DG, Proctor FJ. 1973 - Towards the qualification of post-harvest loss in horticultural produce. ISHS Acta Horticulture 49: III Africa Symposium on Horticultural Crops.

Daniel P. 1993 - What Jane Austin Ate and Charles Dickens Knew. Touchstone/ Simon \& Shuster, New York. 209.

De Silva A, Bolton MD, Nelson BD. 2005 Transformation of Sclerotinia scleratiorum with the green fluorescent protein gene and expression of fluorescence in host tissues. Phytopathology 95, S23.
Dissanayake N, Wickramasinghe DB. 1999 Effect of N, P and $\mathrm{K}$ application on the occurrence and severity of narrow brown leaf spot in different rice varieties. In: Proc. Annual Symposium of DOA 267-276.

Fernando SNU. 1968 - The natural vegetation of Ceylon (Colombo: Lake House Bookshop).

Hale ME Jr. 1980 - The lichen genus Relicina (Parmeliaceae) in India and Sri Lanka. The Bryologist 83, 77-78.

Hale ME Jr. 1981 - A revision of the lichen family Thelotremataceae in Sri Lanka. Bulletin of the British Museum (Natural History), Botany Series 8, 227-332.

Höhnel F. 1908 - Fragmente zur Mycologie V, Nr. 169 bis 181. Akad. Wiss. Wien Math.-naturw. K1., Band 117, 1-48.

Höhnel F. 1909 - Fragmente zur Mycologie VI, Nr. 182 bis 288. Akad. Wiss. Wien Math.-naturw. K1., Band 118, 1-178.

Höhnel F. 1914 - Fragmente zur Mycologie XVI, Nr. 813 bis 875 . Akad. Wiss. Wien Math.-naturw. Kl., Band 123, 1107.

Holliday P. 1995 - Fungus Diseases of Tropical Crops New York: Dover Publications 607, ISBN 0-486-68647-7.

Horak E. 1979 - Astrosporina (Agaricales) in Indomalaya and Australasia. Persoonia 10, 157-205.

Horak E 1980 - Inocybe (Agaricales) in Indomalaya and Australasia. Persoonia 11, 1-37.

Houttyn M. 1783 - Handleiding tot de plant en kruidkunde benevens eene uitvoerige beschrijving der boomen, planten, heesters, kruiden, varens, mossen, bolen grasplanten, volgens het zamenstel van C. Linnaeus 14, 585-698. Amasterdam: Lodewyk van Es.

Jayalal RGU, Wijesundara DSA, Karunaratne V. 2008 - Lichenological studies in Sri Lanka. 13th International Forestry and Environmental Symposium, University of Sri Jayawardhanapra, Sri Lanka 6970.

Jayasinghe CK, Wettasinghe JLPC. 1996 Saprophytic colonization of Geotrichum sp. on Hevea brasiliensisi roots, a condition that resembles white root 
disease. Journal of the Rubber Research Institute of Sri Lanka 78, 102-105.

Jayasinghe CK. 1993 - Natural occurrence of Thanatephorus cucumeris leaf spots on Hevea brasiliensis in Sri Lanka. Plant Pathology 42, 473-474.

Jayasinghe CK, Fernando THPS. 1997 Priyanka UMS. Colletotrichum acutatum is the main cause of Colletotrichum leaf disease of rubber in Sri Lanka. Mycopathologia 137, 53-56.

Jayasinghe CK, Liyanage A de S, Warnapura SS. 1988 - Outbreaks and new records. Collar rot of rubber seedlings caused by Sclerotium rolfsi. FAO Plant Protection Bulletin 36, 189.

Jayasinghe CK, Silva WPK. 1994 - Foot canker and sudden wilt of Hevea brasiliensis associated with Nattrassia mangiferae. Plant Pathology 43, 938940.

Jayasuriya AHM. 1984 - Flora of Ritigala Strict Natural Reserve. Sri Lanka Forester 16, 61-155.

Jayasuriya KE, Wijesundera RLC, Thennakoon BI. 2007 - Effect of rubber petiole cell walls and virulence of strains on secretion of pectic enzymes by Pytophthora meadii. Ceylon Journal of Science (Bio. Sci.) 36, 108-114.

Jayasuriya KE, Thennakoon BI. 2007a - First report of Corynespora cassiicola on Codiaeum variegatum (croton) in Sri Lanka. Ceylon Journal of Science (Biological Sciences) 36, 139-142.

Jayasuriya KE, Thennakoon BI. 2007b Biological control of Rigidoporus microporus, the cause of white root disease in rubber. Ceylon Journal of Science (Biological Sciences) 36, 9-16.

Jayawardena SSBDG, Weerasena LA. 2000 Crop Diversification in Sri Lanka, Department of Agriculture, Peradeniya; Sri Lanka. Jones, D. (1991).

Kader AA. 2005 - Increasing food availability by reducing postharvest losses of fresh produce. Acta Horticulturae (ISHS) 682, 2169-2176.

Karunanayake C, Adikaram NKB, Abayasekara C, Ratnayake Bandara BM. 2007 - Constitutive defences in unripe mango fruit and their role in fruit esistance. Extended Abstract. Proceedings in the third Asian Conference on Plant Pathology, Yogyakarta, Indonesia 263-264.

Karunarathna SC, Vellinga EC, Zhao RL, Bahkali AH, Chukeatirote E, Alva PP, Zhou D, Hyde KD. 2012 - Agaricus hanthanensis, a new species from Sri Lanka Mycoscience (under review).

Karunarathna SC, Yang ZL, Raspé O, Ko Ko TW, Vellinga EC, Zhao RL, Bahkali AH, Chukeatirote E, Degreef J, Callac P, Hyde KD. 2011 - Lentinus giganteus revisited: new collections from Sri Lanka and Thailand. Mycotaxon 118, 57-71.

Ko Ko TW, McKenzie EHC, Bahkali AH, Toanun C, Chukeatirote E, Promputtha I, Abd-Elsalam KA, Soytong K, Wulandari NF, Sanoamuang N, Jonglaekha N, Kodsueb R, Cheewangkoon R, Wikee S, Chamyuang S, Hyde KD. 2011 - The need for re-inventory of Thai phytopathogens. Chiang Mai Journal of Science 38, 625-638.

Kurokawa S, Mineta M. 1973 - Enumeration of Parmeliaceae of Ceylon. Annual Report of Noto Marine Laboratory, University of Kanazawa 13, 71-76.

Leighton WA. 1870 - The lichens of Ceylon collected by G.H.K. Thwaites. Transactions of the Linnean Society of London 27, 161-185.

Liu JK, Phookamsak R, Jones EBG, Zhang Y, Ko-Ko TW, Hu HL, Boonmee S, Doilom M, Chukeatirote E, Bahkali AH, Wang Y, Hyde KD (2011) Astrosphaeriella is polyphyletic, with species in Fissuroma gen. nov., and Neoastrosphaeriella gen. nov. Fungal Diversity 51, 135-154.

Liyanage A de S, Dantanarayana DM. 1983 Association of Fusarium solani with root lesions of rubber (Hevea brasiliensis) showing leaf wilt in Sri Lanka. Transactions of British Mycological Society 80, 565-567.

Liyanage $M$ de $S$, Tejwani KG, Nair PKR. 1986 - Intercropping under coconuts in Sri Lanka. Cocos 4, 23-34.

Maharachchikumbura SSN, Guo LD, Chukeatirote E, Bahkali AH, Hyde KD. 
2011 - Pestalotiopsis - morphology, phylogeny, biochemistry and diversity. Fungal Diversity 50, 167-187

Makhija U, Patwardhan PG. 1992 Nomenclatural notes on some species of Trypethelium. International Journal of Mycology and Lichenology 5, 237-251.

Manamgoda DS, Cai L, Bahkali AH, Chukeatirote E, Hyde KD. 2011 Cochliobolus: an overview and current status of species Fungal Diversity 51, 342.

Moberg R. 1986 - Rolfidium, a new lichen genus from Sri Lanka. Lichenologist 18, 305-307.

Moberg R. 1987 - Lichenes Selecti Sxsiccati Upsaliensis. Fasc. 2 (Nos 26-50). Thunbergia 5, 1-9.

Monica A, Garcia-Solache, Casadevall A. 2010 - Global warming will bring new fungal diseases for mammals. mBio 1, e0006110 doi: $10.1128 / \mathrm{mBio} .00061-10$

Muraleedharan N. 2007 - Control of Frog Eye Spot Disease. In: UPASI Research Highlights 2007, Muraleedharan, N. (Ed.). UPASI, New Delhi 11-12.

Nayanakantha NMC, Gajameragedara S. 2003 - A survey of lichens in the Kandy municipal region. Ceylon Journal of Science (Bio.Sci.) 31, 35-41.

Nugaliyadde L, Dissanayake N, Mitrasena K. 2000 - Advances in pest and disease management of rice in Sri Lanka: Proceedings of the Annual Symposium of the Department of Agriculture, Plant Genetic resources Center, Gannoruwa, Peradeniya, Sri Lanka. ASDA2 409422.

Orange A, James PW, White FJ. 2001 Microchemical methods for the identification of lichens. British Lichen Society 101.

Pegler DN. 1972 - A revision of the genus Lepiota from Ceylon. Kew Bull. 27, 155-222.

Pegler DN. 1977 - A revision of Entolomataceae (Agaricales) from India and Sri Lanka. Kew Bull. 32, 189-220.

Pegler DN. 1986 - Agaric flora of Sri Lanka. Kew Bull. Additional Series 6, Her Majesty's Stationary Office, London.

Petch T, Bisby GR. 1950 - The Fungi of
Ceylon. Peradeniya Manual 6, 111.

Petch T. 1908a - The Phalloideae of Ceylon. Annals of the Royal Botanical Garden of Peradeniya 4, 139-184.

Petch T. 1908b - "The genus Endocalyx Berkeley and Broome" in Annals of Botany 22, 389-400.

Petch T. 1910 - Revisions of Ceylon fungi (part II). Ann. Roy. Bot. Gard., Peradeniya 4, 373-444.

Petch T. 1913 - Termite fungi: a resume. Ann. Roy. Bot. Gard., Peradeniya 5, 303-341.

Petch T. 1915a - The pseudosclerotia of Lentinus similis and Lentinus infundibuliformis. Ann. Roy. Bot. Gard., Peradeniya $6,1-18$.

Petch T. $1915 b-$ Horse-hair blights. Ann. Roy. Bot. Gard., Peradeniya 6, 43-68.

Petch T. 1916a - A preliminary list of Ceylon Polypori. Ann. Roy. Bot. Gard., Peradeniya 6, 87-144.

Petch T. 1916b - Ceylon Lentini. Ann. Roy. Bot. Gard., Peradeniya 6, 145-152

Petch T. 1916c - Revisions of Ceylon Fungi (Part. IV). Ann. Roy. Bot. Gard., Peradeniya 6, 153-183.

Petch T. 1917a - Additions to Ceylon Fungi. Ann. Roy. Bot. Gard., Peradeniya 6, 195-256.

Petch T. 1917b - Revisions of Ceylon Fungi. V. Ann. Roy. Bot. Gard., Peradeniya 6, 307-355.

Petch T. 1919 - Revisions of Ceylon Fungi (Part. VI). Ann. Roy. Bot. Gard., Peradeniya 7, 1-14.

Petch T. 1922 - Additions to Ceylon Fungi II. Ann. Roy. Bot. Gard., Peradeniya 7, 279-322.

Petch T. 1923 - The Diseases of the Tea Bush. 220 pp. London : MacMillan \& Co. Ltd.

Petch T. 1924a - Thread blights. Ann. Roy. Bot. Gard., Peradeniya 9, 1-46.

Petch T. 1924b - Revisions of Ceylon Fungi (Part. VII). Ann. Roy. Bot. Gard., Peradeniya 9, 119-181.

Petch T. 1924c - Ceylon pink-spored agarics. Ann. Roy. Bot. Gard., Peradeniya 9, 201-216.

Petch T. 1924d - Agaricaceae pleuropods Zeylanicae. Ann. Roy. Bot. Gard., Peradeniya 9, 217-227.

Petch T. 1925 - Additions to Ceylon Fungi III. 
Ann. Roy. Bot. Gard., Peradeniya 9, 313-328.

Petch T. 1926a - Additions to Ceylon Fungi IV. Ann. Roy. Bot. Gard., Peradeniya 10, 131-138.

Petch T. 1926b - Rhacophyllus B. \& Br. Trans. Brit. Mycol. Soc. 11, 238-251.

Petch T. 1927 - Revisions of Ceylon Fungi VIII. Ann. Roy. Bot. Gard., Peradeniya 10, 161-180.

Petch T. 1928 - Tropical root disease fungi. Trans. Brit. Mycol. Soc. 13, 238-253.

Petch T. 1945 - Ceylon fungi, old and new. Trans. Brit. Mycol. Soc. 28, 137-147.

Petch T. 1948 - A revision of Ceylon Marasmii. Trans. Brit. Mycol. Soc. 31, $19-44$.

Phoulivong S, Cai L, Chen H, McKenzie EHC, Abdelsalam K, Chukeatirote E, Hyde KD. 2010a - Colletotrichum gloeosporioides is not a common pathogen on tropical fruits. Fungal Diversity 44, 33-43.

Phoulivong S, Cai L, Parinn N, Chen H, AbdElsalam KA, Chukeatirote E, Hyde KD. $2010 \mathrm{~b}-\mathrm{A}$ new species of Colletotrichum from Cordyline fruticosa and Eugenia javanica causing anthracnose disease. Mycotaxon 114, 247-257.

Rossman AY, Palm-Hernández ME. 2008 Systematics of plant pathogenic fungi: why it matters. Plant Disease 92, 13761386.

Seneviratne SN de S, Jeyanandarajah P. 2004 Rice diseases - problems and progress. Tropical Agricultural Research and Extension 7, 30-48.

Sivakumar D, Wijeratnam RSW, Wijesundera RLC, Abeyesekera M. 1997 - Post harvest diseases of rambutan (Nephelium lappaceum) in the Western Province of Sri Lanka.Journal of the National Science Council, Sri Lanka 25, 225-229.

Sivanathan S, Adikaram NKB. 1989a Latency of Infection in unripe avocados by Colletotrichum gloeosporioidesis not due to inadequate enzyme potential. Journal of Phytopathology 125, 110116.
Sivanathan S, Adikaram NKB. 1989b Biological activity of four antifungal compounds in immature avocado. Journal of Phytopathology 125, 97-109.

Tseng Y, An KM, Esue O, Wirtz D. 2004 The bimodal role of filamin in controlling the architecture and mechanics of F-actin network. J. Biol. Chem. 279, 1819-1826.

Udayanga D, Liu X, McKenzie EHC, Chukeatirote E, Bahkali AHA, Hyde KD. 2011 - The genus Phomopsis: biology, applications, species concepts and names of common phytopathogens. Fungal Diversity 50, 189-225.

Vandermeer J, Perfecto I, Liere H. 2009 Evidence for hyperparasitism of coffee rust (Hemileia vastatrix) by the entomogenous fungus, Lecanicillium lecanii, through a complex ecological web. Plant Pathology 58, 636-641.

Vezda A, Brunnbauer W, Breuss O. 1997 Flechten aus Sri Lanka. Annalen des Naturhistorisches Museum Wien Botanische 99B 737-742.

Waller JM, Bigger M, Hillocks RA. 2007 Coffee pests, diseases and their management. Wallingford, Oxfordshire: CABI. P, ISBN 1845931297.

Wijerathnam RSW, Sarananda KH. 2008 Occurrence of crown-rot in 'Embul' bananas. Post harvest technology group, Agro \& food technology div., CISIR, Gannoruwa, Peradeniya.

Wijesundera RLC, Kulatunga SM. 1993 Differences between three Poria hypolateritia isolates in Sri Lanka. Journal of the National Science Council, Sri Lanka 21, 227-233.

Wikee S, Udayanga D, Crous PW, Chukeatirote E, McKenzie EHC, Bahkali AH, Dai DQ, Hyde KD. 2011 Phyllosticta - an overview of current status of species recognition. Fungal Diversity 51, 43-61.

\section{Web references}

http://www.srilankanwebdesign.com/coconut1/ http://www.knowledgebank.irri.org/IPM/index. php/false-smut 
Current Research in Environmental \& Applied Mycology Doi 10.5943/cream/2/1/2 http://www.agridept.gov.lk/index.php/en/croprecommendations/809

http://www.agridept.gov.lk/

http://www.customs.gov.lk/docs/25279.pdf 